\title{
号36回日本良導絡自律神経学会発表
}

\section{腹症より相関へ（第VI報）続 2}

\author{
仙腸 関節 取穴法
}

○症例16「表 V- (イ〜二)」（省略）

〔患者名〕

今 53 才 (石工)

〔主 訴) 腰痛、15年前より腰痛反復、治療を 受け腰痛好転すると、すぐに石切りの重労働に 従事するので間も無く腰痛再発と云う工合で、 治療すると 1 週間位で好転していた。併し今回 は約 2 力月間、整形外科医、鍼尒師に依る治療を 受けているが一向に好転しない。整形では $\mathrm{L}_{3}$ 、 $\mathrm{L}_{4}$ の変形症と診断された。

〔初診〕昭和59年10月29日

〔腹症〕左 $\left(\mathrm{A}^{\prime} \times \mathrm{a}\right)$ 、右 $\left(\mathrm{A}^{\prime} \times \mathrm{m}\right)$ 、右 $(\mathrm{E} \times \mathrm{e})$ 、右 $(\mathrm{M} \times \mathrm{m})$ 亿圧痛。特任右 $(\mathrm{M}$ $\times e) 、(M \times m)$ は著明。

〔治 療〕両側 $(\mathrm{S}-\mathrm{A}) \cdot(\mathrm{S}-\mathrm{E}) \cdot(\mathrm{C}$ - $\mathrm{L} \times \mathrm{L} \cdot \mathrm{A} \cdot \mathrm{P})$ 亿刺針、低周波15分通電。

$\rightarrow(\mathrm{HI}) 、$ ハイコレックス貼付。

〔测定値〕治療前は右 $\mathrm{H}_{5} \uparrow$ 。治療後では右 $\mathrm{H}_{5}$ は不変、平均値は $4 \rightarrow 7$ に上昇の傾向を認めた。 〔経 過〕

10月30日 …不変。(腰痛、以前之同様) 前法治療。 11月 2 日 $\cdots$ 稍々、腰痛軽減してくる。前法治療。 11月 5 日 …腰痛消失（卅）、前法治療。此の日 の治療前の测定值は $\mathrm{F}_{1} \uparrow 、 \mathrm{~F}_{4} \uparrow 、$ $\mathrm{F}_{5} \downarrow$ で治療後は、右 $\mathrm{F}_{1}$ 、右 $\mathrm{F}_{4} \uparrow$ 、 右 $\mathrm{F}_{5} \downarrow$ となり平均值は $13 \rightarrow 14$ で殆 ど変化を認めなかった。 此の例では病位に直接関係のない左側の $\mathrm{F}_{1}$ 、 $\mathrm{F}_{4} 、 \mathrm{~F}_{5}$ のバラツキは治療直後、すべて調整さ れている。尚、患者は右下肢 $\mathrm{F}_{4} \sim \mathrm{F}_{5}$ 領域の疼 痛ああったが、全治した。併し、初揨時の治療 前と比較すると11月 5 日の測定值はバラツキか 増加している。

○症例17「表 $\mathrm{VI}$ - (イ〜ハ)」（省略）

〔患者名〕 + 59才（主婦）

〔主 訴〕右膝関節痛 ( $\mathrm{F}_{4} 14$ : 委中、 $\mathrm{F}_{5} 12$ :
静岡県杉山栄一

陽関）腰背肩凝りを伴う。約 6 年前より膝関䬣 ロイマチスの診断の下に某温泉病院にて治療を 受け、又、鍼负師の治療も併用して継続してい るが跭痛が少しも好転しない。

〔初診〕昭和59年10月30日

〔腹 症〕両側 $\left(\mathrm{A}^{\prime} \sim \mathrm{M}\right) \times \mathrm{a}$ 、䜪状乫起 腾 のVM上、 $(B \sim E) \times e$ 、両側 $S(M \times m)$ に圧痛。特に右側 $\left(A^{\prime} \sim M\right) \times a 、(B \sim E)$ $\times \mathrm{e}$ は著明で病位と同側である。

〔治 療〕低周波、針を用いず、ハイコレック スのみを使用。

i ) 両側 $(\mathrm{S}-\mathrm{E})$ ・ $(\mathrm{S}-\mathrm{A})$ にハイコレッ クス貼付 $\rightarrow$ 主訴…（H）。併し、右 $\mathrm{F}_{5} 12$ の疼 痛…(一)。腹症は（冊）となったが両側 S（M $\times \mathrm{m})$ の圧痛… ( - $)$ 。

ii) 両側 $(\mathrm{C} ・ \mathrm{~L} \times \mathrm{L} \cdot \mathrm{A} ・ \mathrm{P})$ ハイコレック 不貼付 $\rightarrow$ 膝関節 $\cdots($ ( $\mathrm{H}) 、 \mathrm{~S}(\mathrm{M} \times \mathrm{m}) \cdots(\mathrm{H})$ 。 〔測定値〕测定前、 $\mathrm{F}_{1} \uparrow 、 \mathrm{~F}_{4} \uparrow$ 、右 $\mathrm{F}_{6} \downarrow$ で あったが治療直後、 $\mathrm{H}_{6} \downarrow$ 、右 $\mathrm{F}_{5} \downarrow$ 、左 $\mathrm{F}_{6} \downarrow$ があらたに現れた。平均值は治療前後変化なく 10である。

〔経 過〕11月 2 日…腰背有の疑り、痛みは、 すっかり無くなった。膝の痛みす可なり好転。 併し、階段を降りる際、疼痛あり。前法治療。 11月 6 日”..階段を降りる際の痛みは僅かとなっ た。此の日の治療前の測定值は $\mathrm{F}_{1} 、 \mathrm{~F}_{4} \uparrow$ のみ で他のバラッキは調整された。現在、週一回治 療を継続中であるが経過良好である。

○症例18「表 VII-（イ〜ハ）」（省略）

〔患者名〕 우 52才（主婦）

〔主 訴〕両側滕関節痛（6 年程前加ら発病、 ロイマチス性、時々、関節穿刺排液を実施して きたが疼痛柽減は一時的である。最近は関節内 液眝溜は殆ど認められなくなったが、坐位不 能、歩行に依る疼痛は不変。高血圧、冠不全あ 
り。腰痛を伴う。

特に左膝関節内側 $\left(F_{2} 9\right)$ 疼痛著明。

〔初昣〕昭和59年10月23日

〔腹 症了左 $\left(A^{\prime} \times m\right)$ 、両側 $S(M \times m)$ 圧 痛。左滕関節が右より強いのに腹症では左 $\left(A^{\prime}\right.$ $\times \mathrm{m}$ ) のみに強い王痛がある。此の場合、 $\mathrm{S}(\mathrm{M}$ $\times \mathrm{m})$ が関節痛に、より関連性があると考えら れる。 $\mathrm{S}(\mathrm{M} \times \mathrm{m})$ は肩胛骨相関帯では腰、膝 亿相関している。（未発表）

〔治 療〕方法としてカンポリジン注射のみを 実施した。

$(\mathrm{S}-\mathrm{A}) \cdot(\mathrm{S}-\mathrm{E})$ Kカンポリジン $2 \mathrm{cc}$ を分 割注射。注射敦はょの箇所に可能な限り梁刺 (垂直)。 楽に坐れる様になる。主訴…(卅)、 腹症…(卅)。

〔測定値】治療前 $F_{1} \uparrow 、$ 右 $F_{2} \uparrow 、 F_{5} \downarrow$ であ ったが治㞠後10分では、すへての良導絡は調整 され、平均值は14 $\rightarrow 5$ に低下した。

〔経 過〕10月26日”..疼痛可なり好枟し歩行に 際しては全く痛みを感じない。坐るととあ可能 となったが疼痛を少し伴う。前法治療。此の時 の測定值は $F_{1} \uparrow$ 、右 $F_{5} \downarrow$ て、 $F_{2}$ は調整され ている。 $\mathrm{F}_{2}$ 9の疼痛改善の為と考元られる。以 後、週一回つつ治療中であるが経過良好である。 ○症例19「表XII一（イ〜口）」（省略）

〔患者名〕 우67才

〔主訴」腰痛（左）、局凝り（両侧）（2力 月前より)

〔初㟝) 昭和59年 8 月11日

〔腹症〕左 $\left(A^{\prime} \times m\right)$ 、両側 $(M \times m)$ 圧痛。

〔治 療〕再側 $(S-E) \cdot(S-A) \cdots$ 刺針

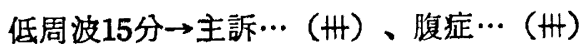

〔測定值〕治療前、 $\mathrm{H}_{1} \uparrow 、 \mathrm{H}_{4} \downarrow$ 、左 $\mathrm{H}_{5} \uparrow 、$ $\mathrm{H}_{6} \uparrow 、 \mathrm{~F}_{3} \downarrow 、 \mathrm{~F}_{5} \downarrow$ 、左 $\mathrm{F}_{6} \downarrow$ であったが治療 後、F $3 、 F_{5} 、 F_{6}$ は調整された。左 $\mathrm{H}_{1} \uparrow 、$ $\mathrm{H}_{4} \downarrow 、 \mathrm{H}_{6} \uparrow$ は調整されてないが其のバラツキ の程度は減少している。治療前、平均值25であ ったが治療後は 8 亿低下している。

〔経 過〕 8 月15日…主訴…(H)、前法治療。 以後、通院なし。一回の治療で治瘾した。 $(11$ 月20日、気管支炎で来院時での患者証言） ○症例20「表IX一（イ〜木）」（省略） 〔患者名〕 우71才
〔主挀〕夜間湤しい䕎発作（4日前より）。 腰背有の疑り、痛みを伴う。腰、下肢の炩え。

〔初診〕昭和59年11月 1 日

〔腹 症〕両側 $(A \sim B) \times a 、 V M 、\left(A^{\prime} \times\right.$ $\mathrm{m}) 、(\mathrm{E} \times \mathrm{e})$ 、両側 $\mathrm{S}(\mathrm{M} \times \mathrm{m})$ 亿圧痛。

〔治 療〕両側 $(S-E) \cdot(S-A) \cdot(C$ - L $\times \mathrm{L} \cdot \mathrm{A} \cdot \mathrm{P})$ に刺針、低周波15分通電、 众 3 壮を加える。

〔測定値】治療直前では、 $\mathrm{H}_{2} \downarrow 、 \mathrm{H}_{3} \downarrow$ 、右 $\mathrm{F}_{1} \downarrow$ 、左 $\mathrm{F}_{2} \uparrow 、$ 右 $\mathrm{F}_{2} \downarrow 、 \mathrm{~F}_{3} \downarrow$ 、右 $\mathrm{F}_{4} \uparrow 、$ $\mathrm{F}_{5} \downarrow$ とバラツキ大であったが低周波通電後 10 分では $\mathrm{H}_{2} 、 \mathrm{H}_{3} 、$ 右 $\mathrm{F}_{3} 、$ 右 $\mathrm{F}_{4} 、 \mathrm{~F}_{5}$ は調整さ れ平均値は $25 \rightarrow 18$ 亿低下した。此の時点で同 一䈯所に更に尒 3 壮を加えて10分後に測定した 処、表IX-Cに記載してある通りバラッキは再 び大となり平均値は27と上昇した。

〔経過〕11月 2 日…昨夜は咳む治まり安眠、 前法治療。

此の日の測定値は、治療前。右 $\mathrm{H}_{6} 、 \mathrm{~F}_{1}$ 、右 $\mathrm{F}_{8}$ 、 $\mathrm{F}_{\text {小 }} \mathrm{F}_{5}$ 、右 $\mathrm{F}_{6}$ とバラツキがあったが治療後 はバラツキ隇少し平均值は $40 \rightarrow 15$ と低下した。 11月 5 日、治痖。

○症例21「表X-(イ〜ハ)」参照

〔患者名〕占 74才（石工）

〔主 訴〕右腰背肩痛、右項頸部疼痛 ( 6 年前、 車にて現場へ向う途中、約 $20 \mathrm{~m}$ ぼ゙の高さの崖 加ら車でと転落、意識不明のまま、近くの某大学 附属病院へ搬送され頚椎、腰椎骨折で入院治療 6 力月間。入院中より主訴甚しく、退院後む多 くの専門医、銊尒師に依る治療を受けたが症状 一進一退で好転せず、不治のあのと暲めていた。

〔初晾〕昭和59年10月23日

〔腹 症〕両側 $\left(A^{\prime} \times a\right) \cdot\left(A^{\prime} \times m\right) \cdot S$ $(\mathrm{M} \times \mathrm{m})$ に圧痛。特に後二者に圧痛が強い。

[治 療] $(\mathrm{S}-\mathrm{E}) \cdot(\mathrm{S}-\mathrm{A}) \cdot(\mathrm{C} \cdot \mathrm{L}$ $\times \mathrm{L} \cdot \mathrm{A} \cdot \mathrm{P})$ に刺針低周波 15 分通電。ハイコ レックス貼付。 $\rightarrow$ 主訴…（卅）。

〔測定〕治療前、左 $\mathrm{H}_{5} \downarrow$ 、右 $\mathrm{F}_{1} \uparrow 、 \mathrm{~F}_{4} \uparrow$ 、右

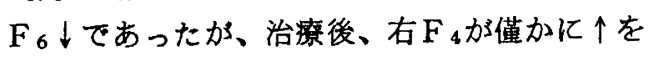
示したのみで他の良導絡はすへて調整された。

〔経 過〕11月 2 日...経過良好。併し、項部凝 りが少し残る。以前の様に疼痛を伴った疑りで はない。此の日の治療前の測定值は $\mathrm{F}_{4} \uparrow$ を示 
すのみで、他は、生理的範囲内に調整されてい る。現在、治療継続中であるが、経過、益々、 良好となっている。

○症例22「表XI一（イ〜二）」参照

\section{〔患者名〕 우 68 才}

〔主 訴〕左膝関節痛 ( 3 年前より膝関節腫脹 疼痛。時々、関節穿刺。現在は腫脹は殆ど認め られないが、歩行時、坐位に依る関節痛あり。 腰痛、局凝りを伴う）（膝関節内側の痛）

〔初 診〕昭和59年10月24日

〔腹症〕右 $\left(A^{\prime} \sim B\right) \times a$ 、左 $\left(A^{\prime} \times a\right)$ 、 心窩部より臍に至る $\mathrm{VM}$ 上、両側 $\left(\mathrm{A}^{\prime} \times \mathrm{m}\right)$ 、 右 $\left(A^{\prime} \sim B\right) \times e$ 、左 $\left(A^{\prime} \times e\right)$ 、両側 $S(M$ $\times m)$ に压痛。特に右 $\left(A^{\prime} \times a\right)$ 、左 $\left(A^{\prime} \times\right.$ $\mathrm{m})$ 、両側 $\mathrm{S}(\mathrm{M} \times \mathrm{m})$ 亿著明。主訴之密接に 関連するものは $\mathrm{F}\left(\mathrm{A}^{\prime} \times \mathrm{m}\right)$ と考える。

〔治 療〕両側 $(\mathrm{S}-\mathrm{E}) 、(\mathrm{~S}-\mathrm{A}) 、(\mathrm{C} \cdot \mathrm{L} \times$ $\mathrm{L} ・ \mathrm{~A} ・ \mathrm{P})$ にカンポリジン注射。ハイコレッ クス貼付。 $\rightarrow$ 主訴・随件症状 (H)、腹症 (W)。

〔測定值〕右 $\mathrm{H}_{5} \uparrow$ 、右 $\mathrm{F}_{5} \uparrow$ 、左 $\mathrm{F}_{5} \downarrow$ を治療 前示しているが治療後は $\mathrm{F}_{5}$ は調整され右 $\mathrm{H}_{5}$ の みバラツキを呈している。

疼痛は $\mathrm{F}_{2} 9$ を中心とした領域であるが、測定 の結果では $\mathrm{F}_{2}$ と表裹関係にある $\mathrm{F}_{5}$ 、及び此れ と共䡉関係にある $\mathrm{H}_{5}$ にバラッキを認めたと考 えられるが、肩凝りがあるので $\mathrm{H}_{5}$ のバラッキ が出現したとも考えられる。亦、腹症と主訴と の関連性は左 $\left(\mathrm{A}^{\prime} \times \mathrm{m}\right)$ が最む高いが 既に述へ た様に $\mathrm{S}(\mathrm{M} \times \mathrm{m})$ は膝にあ相関する部位であ り、此処は $\mathrm{H}_{4}$ 領域であるが、 $\mathrm{F}_{5}$ とあ関連する 所であるので $\mathrm{F}_{5}$ のバラツキがみられたとも解 䣋出来る。亦、 $\mathrm{S}(\mathrm{M} \times \mathrm{m})$ は肩之も相関する 部位なので $\mathrm{H}_{5}$ とあ関連性が強い所であり $\mathrm{H}_{5}$ のバラツキ出現と解するととも可能である。勾 論、F 4 領域にもある訳で、此の様な意味に於て、 $\mathrm{S}(\mathrm{M} \times \mathrm{m})-\mathrm{H}_{4} 11$ (天宗)一は $\mathrm{H}_{4} 、 \mathrm{H}_{5} 、 \mathrm{~F}_{4} 、$ $\mathrm{F}_{5}$ の四重支配を受けている重要な良導点であ り、相関带としては、項、頸、肩、背、腰、上肢、 㮏、腹部のm帯、下腹部と広般な関係を有する 処である。私が広義の腹症の中に $\mathrm{S}(\mathrm{M} \times \mathrm{m})$ を加えているのは此の様な理由からである。

〔経 過〕11月 7 日”歩行に際しての疼痛は改 善されたが、昼間、畑仕事をする為か、夜間、
関節痛あり。腰、肩の工合は可なりよい。 前法治療の他に左膝に E A P 。 測定值は治療前、わづかに左 $\mathrm{F}_{5} \downarrow$ をみるのみ で他は全部調整されているが、治療後は全良導 絡が生理的範囲内に調整された。

11月16日．..歩行に依る疼痛は全く無くなったが 坐位、及び夜間疼痛あり。

治療…今までの治療ではもう一歩と云う所で切 れ味がよくないので仙骨部HM相関帯を加える ことにした。先つ $\mathrm{S}_{2}$ 直下の $\mathrm{HM}$ 上に $\mathrm{EA} \mathrm{P} \rightarrow$ 坐位をとっても痛くないと云う。次に $(\mathrm{S}-\mathrm{A})$ と $(\mathrm{S}-\mathrm{E})$ の中点一 $(\mathrm{S}-\mathrm{M})$ （図 3、図 5 の 2 参照）一にE P A $\rightarrow$ 坐っても全く痛みがな く膝の抵抗を感じなくなった。（ $\mathrm{S}-\mathrm{M} ） \cdot \mathrm{S}_{2}$ 直下のHM、 $(\mathrm{C} \cdot \mathrm{L} \times \mathrm{L} \cdot \mathrm{A} \cdot \mathrm{P})$ 亿刺釬、 低周波 15 分。ハイコレックス貼付。治療終了 後、今までの治療後の工合と違って、治ってし まった様な感じだと云う。以後、週一回治療中 であるが経過良好である。

$\mathrm{S}_{2}$ 直下〜 仙腸関節の中点を結ふ心領域は膝関 節への相関帯とすることが出来る。

仙腸関節取穴のみで勃果不充分な場合は、仙 骨HM相関帯を加えると有効である。

○症例23「表XII一 (イ〜ホ)」参照

\section{〔患者名〕 웅（旅館炊事婦）}

〔主 訴〕右前膊激痛（三日前、早朝、大きい 釜を「かまど」にかけようとして釜のッバと 「かまど」との間に右前膊部を狭んでしまったが 其の途端に前膊部に激痛を覚え、右上肢が时を 境に「く」の字に曲ったきり全く動かすことが 出来なくなってしまった。直ぐに救急病院にて 治療を受けたが、激痛去らず、指も曲げるとと が出来ない。診察してみると右膊橈筋が強直性 にもりあがっており肘から手指にかけて浮腫を 軽度みとめる。（病名 外上髁炎）

〔初診〕昭和59年11月13日

〔腹 症〕右 $\left(\mathrm{A}^{\prime} \times \mathrm{a}\right)$ 亿柽度压痛、右 $\mathrm{S}(\mathrm{M}$ $\times \mathrm{m})$ に強い圧痛。右 $\mathrm{S}(\mathrm{M} \times \mathrm{m})$ の圧痛が主 訴との関連性が強いと考えられる。

〔治 療〕最初両側 $(S-E) \cdot(S-A) \cdot$

$(\mathrm{C} \cdot \mathrm{L} \times \mathrm{L} \cdot \mathrm{A} \cdot \mathrm{P})$ 亿型の如く刺針、低周 波15分 $\rightarrow$ 主訴…（土）。

次にE A P を用いて有効な治療点を探索してみ 
る。先つ、最初の取穴は正確であったかどうか チェックしてみる。最初の治療点は腹臥位で正 確に取穴したつもりであったが、今度はベット の椂に腰かけさせて、チェックしてみると右 ( $\mathrm{S}-\mathrm{A})$ が $1 \mathrm{~cm}$ ほど内側（HM寄り）へずれ ていたので、取穴し直してEAPを行った処、 「く」の字に曲った上肢を、疼痛はあるが真直 ぐに伸し指を握るととも可能となった。更にH $\mathrm{M}$ 上で $\mathrm{S}_{3}$ 直下に E A P $\rightarrow$ 上肢、指を動かして あ全く痛みなし。てれらの治療点にハイコレッ クス貼付。

（S－A）は正確にS I P I の位置で仙骨との 半関節部位に取穴しなりれば無効であるととを 示している。亦 $\mathrm{S}_{3}$ と $(\mathrm{S}-\mathrm{A})$ を結ふ領域 は上肢手指に対する相関帯であるととを教えて いる。

〔測定值〕治療前、左 $\mathrm{H}_{1} \downarrow$ 、右 $\mathrm{H}_{4} \uparrow 、 \mathrm{H}_{5} \downarrow$ 、 右 $\mathrm{F}_{1} \uparrow 、 \mathrm{~F}_{2} \uparrow 、 \mathrm{~F}_{6} \uparrow 、$ 主訴は右 $\mathrm{H}_{1}$ の前膊領 域であるが、右 $\mathrm{H}_{1}$ はバラッキなく共䡉関係に

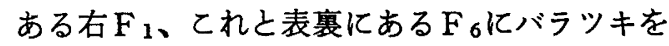
認め、とれが疼痛部位に関連するものと考えら れる。治療後の測定值は左 $\mathrm{H}_{1}$ 、右 $\mathrm{H}_{4}$ が調整さ れたのみである。平均値の変動も殆ど認められ なかった。

〔経 過〕 11 月 14 日…午前10時、来院。昨日の 夕方までは疼痛は感じなかったが昨夜は再び痛 み強く就眠不能となった。

治療として、先つ、「経絡の流注方向」の様な あのが仙腸関節〜腸骨櫛の領域にあるのか？若 しあるとすれば、1600ガウスと云う比較的強力 な、磁石であるから極性を考虑しなければ?と の想定の下にチェックしてみた処、次の様な結 果を得た。いつれも貼付後 5 分のものである。

1) 右 $(\mathrm{S}-\mathrm{A})$ KN極 右 $(\mathrm{C} \cdot \mathrm{L} \times \mathrm{L} \cdot \mathrm{A}$ -P) $\mathrm{S}$ 極 $\rightarrow$ 疼痛軽減の傾向。

口) 右 $(\mathrm{S}-\mathrm{A}) \mathrm{N}$ 極 右 $(\mathrm{C} \cdot \mathrm{L} \times \mathrm{L} \cdot \mathrm{A} \cdot$

P) $\mathrm{N}$ 極 $\rightarrow$ 疼痛増加の傾向。

八) 右 $(\mathrm{S}-\mathrm{A}) \mathrm{S}$ 極 右 (C・ $\mathrm{L} \times \mathrm{L} \cdot \mathrm{A} \cdot$

P) $\mathrm{N}$ 極 $\rightarrow$ 疼痛、稍々軽減の傾向。

二) 再び右 $(\mathrm{S}-\mathrm{A}) \mathrm{N}$ 極 右 $(\mathrm{C} \cdot \mathrm{L} \times \mathrm{L} \cdot$ $A \cdot P) S$ 極 $\rightarrow$ 疼痛可なり軽減の傾向。

以上の結果加 $(\mathrm{S}-\mathrm{A}) 、(\mathrm{C} \cdot \mathrm{L} \times \mathrm{L} \cdot \mathrm{A}$

- P) は夫々、異極の磁石貼付が有効で特に前
者にN極、後者に S 極がよいとと、亦、経絡的 な流注方向があり、且つ、経絡的な一方向のみ でなく方向の相反する二方向であり、特に腰 $\rightarrow$ 腹部方向への流注に治療上は意味があると考え たい。乙れは、経絡的な考え方即ち、「気」は 募穴のある腹部から俞穴のある背部へ流れると 云う考え方に逆行するあのであり、且つ、此の 様な想定は飛躍し過ぎの誹を免れないが、私は 経験上、 $(\mathrm{S}-\mathrm{A}) \rightarrow(\mathrm{S}-\mathrm{E}) \rightarrow(\mathrm{C} \cdot \mathrm{L} \times$ $\mathrm{L} \cdot \mathrm{A} \cdot \mathrm{P})$ 方向への流注を想定して磁石貼付 を行っている。

此の日の測定值は治療前右 $\mathrm{H}_{1} 、 \mathrm{H}_{2} 、 \mathrm{H}_{3}$ 共 $\uparrow 、$ 右 $\mathrm{H}_{6} \uparrow 、 \mathrm{~F}_{3} \downarrow 、 \mathrm{~F}_{4} \downarrow 、 \mathrm{~F}_{5} \downarrow$ でバラッキ増 大し、今日は前膊 $\mathrm{H}_{5} 、 \mathrm{H}_{2}$ 領域にあ疼痛を覚え る様になったが、此の前兆は既に初診時の測定 時に $\mathrm{H}_{5} \downarrow 、 \mathrm{H}_{5} 、 \mathrm{H}_{2}$ の共䡉関係にある $\mathrm{F}_{2}$ 、右 $\mathrm{F}_{5} \uparrow$ として出現していた。低周波、ハイコレ ックス貼付後の測定では $\mathrm{H}_{1} 、 \mathrm{H}_{2} 、 \mathrm{H}_{3} 、 \mathrm{H}_{6} 、$ $\mathrm{F}_{3} 、 \mathrm{~F}_{4} 、 \mathrm{~F}_{5}$ のバラッキは調整され再び、最 初の疼痛部位 $\mathrm{H}_{1}$ の共䡉関係化ある右 $\mathrm{F}_{1} \uparrow$ が出 現している。

11月14日午後 6 時、再度、来院。疼痛甚しく堪 えられないと云う。前法治療後、疼痛は軽減さ れたが、此の時の治療後の測定值は表XII-Eに 示す様に、全体的にバラッキは減少している。 夜間、疼痛発作に備えてインダシン坐薬 1 ケを 投与。

11月15日...経過良好。上肢指を動かしても余り 痛くない。とれは坐薬が有効であったのか或は 両者併用した為に有勃であったのか何れともと れるが、症状の余りに強いときは両者併用が必 要である。

11月16日．疼痛わずかに残存するのみ。筋肉の 腫脹、強直も緩解した。

○症例24「表XIII一 (イ ロ )」参照

〔患者名〕合 38才（会社員）

〔主 訴〕ギックリ腰（三日前、東京工場へ機 械の据えつけに出張、 $10 \mathrm{~kg}$ 位の機械の部品を 持ちあげた途端に激しい腰痛、救急車にて搬送 され加療。どうやら家まで帰って来たが、まだ 可なり疼痛強く上半身を曲げることも伸ばすと とあ困難である。

〔初 診〕昭和59年11月16日 
〔腹症了肥満体。左右 $\left(\mathrm{A}^{\prime} \times \mathrm{a}\right)$ 、右 $(\mathrm{B} \times \mathrm{a})$ 、 両側 S $(M \times m)$ に、わずかの痛あるのみで、 症状の強さに比し、腹症は軽度である。

〔治療〕仏骨HM上の相関带を加えるべく此 処にEAPを行ってチェックしてみる。

i) $\mathrm{S}_{1}$ 直下のHM EAP $\rightarrow$ 主挀 $(+)$

ii) $\mathrm{L}_{5} \sim \mathrm{S}_{1}$ のHM EA P $\rightarrow$ 主訴（H)、此の 部位が相関しているととがわかる。従って、

iii) $\left(\mathrm{L}_{5} \sim \mathrm{S}_{1}\right)$ のHM・ $(\mathrm{S}-\mathrm{E}) \cdot(\mathrm{C} \bullet$ $\mathrm{L} \times \mathrm{L} \cdot \mathrm{A} \cdot \mathrm{P})$ 刺針低周波15分、ハイコレッ クス貼付 $\rightarrow$ 治療直後 (H)。

〔湘定值〕治療前、右 $\mathrm{H}_{4} \downarrow 、 \mathrm{H}_{5} \downarrow$ 、右 $\mathrm{H}_{6} \downarrow$ 、 $\mathrm{F}_{1} \uparrow 、 \mathrm{~F}_{2} \uparrow 、$ 左 $\mathrm{F}_{3} \uparrow 、 \mathrm{~F}_{4} \uparrow$ であったが治療 直後は $\mathrm{H}_{1} \downarrow \mathrm{H}_{3} \downarrow$ 、左 $\mathrm{H}_{4} \downarrow 、 か ゙$ 新しくバラツキ をみ廿たが、平均値は $22 \rightarrow 13$ と低下している。

〔経 過〕11月19日…三日後に、もう一度治療 する様、初朗時に指示しておいたのであるが、 先日の治療で、其の夜加ら安眠出来、其の後、 痛みがなくなったので、治療して貫はなくとも よいと電話連絡あり。

\section{ま とめ}

腹症を消去し、てれに依って主即を改善させ ようと試み、頭部、項、有関節、躯幹、四肢の 領域に私なりの相関帯なるものを設定し、追究 して来たのであるが、今回の仙腸関節取穴法は 治療点の数も少く（四ケ所〜六ケ所）仙腸関節 と云う限られた極くせまい範囲内に取穴するも のであって、手技は極く簡単である。亦、その 勃果は今までの相関帯治療の中で最も切れ味が 良く、永続効果も大である。例えば、関節症或 は関節ロイマチスによる関節痛に対しては、従 来の相関帯治療では容易に疼痛を除去出来ない 場合が多かったが、今回の方法では、他の東西 両医学的治療での無効例に対しても有効な場合 を、しばしば経験している。又、疼痛性矣患の みならず、我々が日常よく遭遇する呼吸器系、 循環器系疾患、消化器系疾患でも、主訴は改善 され易い。せまい範囲の仙腸関節取穴が何故、 此の様に弩効するかを考えるとき、それは腹症 消去之密接な関連性を有する部位であるからで あろう。腹症と云うすのあ見方を変えればバラ ンスの問題であり、その為には、体全体のバラ ンスの中心となるへき部位に治療点をとれば有
効ではないだろうかと云うことは容易に想像出 来ることである。此の様な発想の上に立って、 骨盤部位を考えた。併し、骨盤のどの領域に治 療点を設定するかで迷ったが、最初、腹症消去 には鼠蹊部に設定するのがよいと考え、腹部相 関帯の区分 (A帯 E帯) と鼠蹊部、䎵骨結合 上椂との交点に夫々、EAPを行い、腹症消去 をチェックしたが、期待した程の結果を得るこ とが出来なかった。そてで、今度は骨盤背側部 である仙腸関節に取穴しEAPを行った処、腹 症消去を高率に実現するととが出来た。しかす 左右の腸骨後上棘、腸骨後下棘の四ケ所のみの 治療点で腹症消去を認めたてとは予想外であっ た。亦、良導絡調整の面から眺めても、従来の 方法では四肢、背部に取穴しなければならない が、仙腸関節取穴法では四点〜六点の取穴で充 分である。乙れは此の領域が全身のバランスの 要であり此処に 取穴するととは体の上下、左 右、前後と云う工合にバランスを考え乍ら取穴 する必要がないととを意味している。併し、そ の奏効機序は不明であり、軽々しく測断する事 は許されないが、視床下部、丒椂系が関与して いるととは想像できる。且つ、視床下部に於て あ身体各部位に対応する相関帯的な局所性があ るのではないかと、考えている。単なるエンド ルフィン分泌説のみでは相関帯現象は説明不可 能である。今迄の症例であ、しばしば強れてお いたが、仙腸関節部位には相関帯が存在すると とが判明した。此の事と、仙骨HM上の相関帯 とを組み合せて「仙骨相関帯」なるものを考え 目下検討中である。

\section{結論}

1. 仙腸関節取穴法は腹症消去を強力に行い、 それに依って主訴の改善を罒るととが出来る。

2. 此の取穴法は全良導絡のバラツキを調整す る。

3. 腹症 (広義) の中、 $\mathrm{S}(\mathrm{M} \times \mathrm{m})$ 亿圧痛、 その他の異常を認めた場合は $(\mathrm{C} ・ \mathrm{~L} \times \mathrm{L} ・ \mathrm{~A}$

・P）を治療点として加える。

4. 手技は極めて簡単であり、再現性に優れて いる。

以上

(本研究の要旨は第36回日本良導絡自律神経学 会に於て報告した。） 

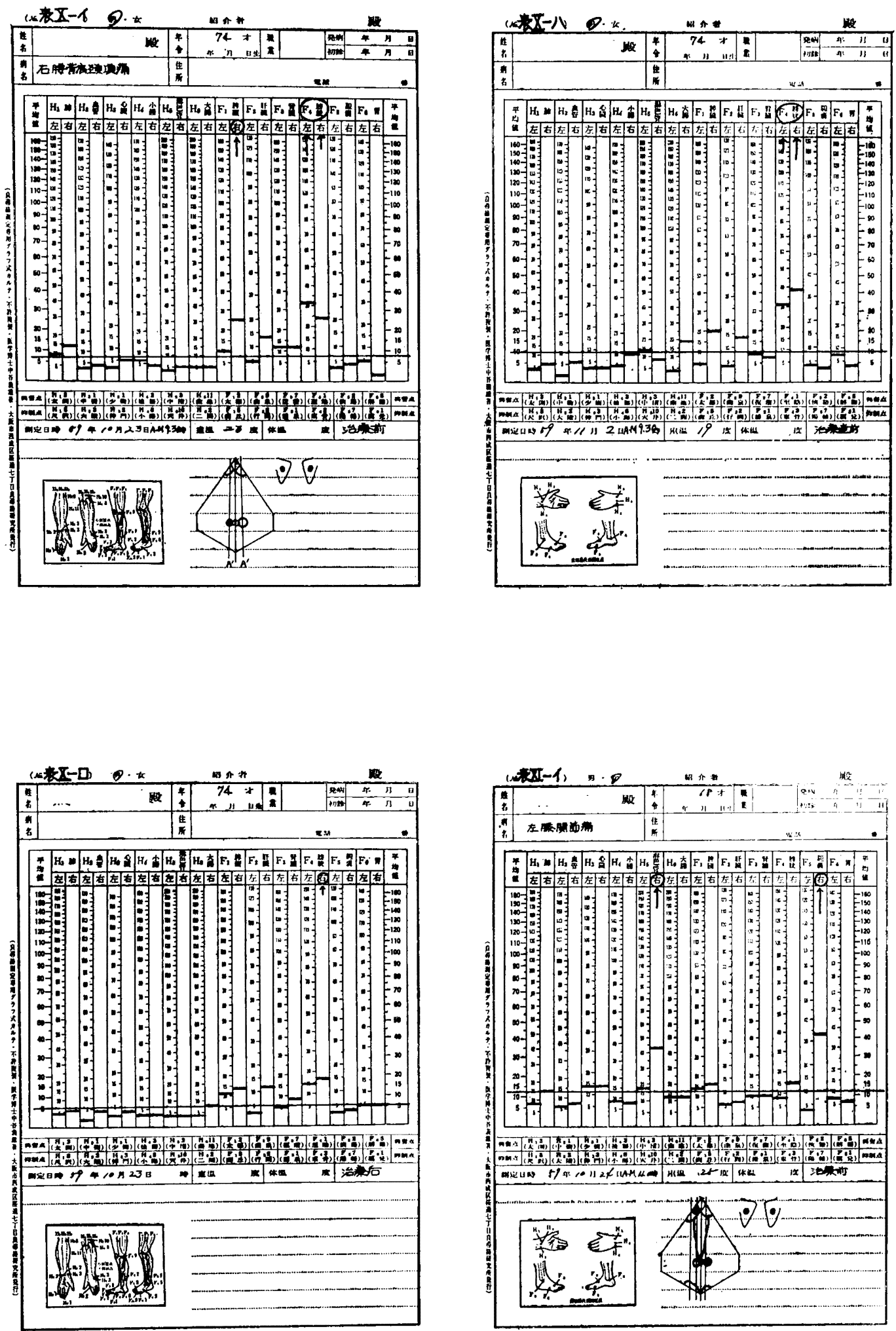



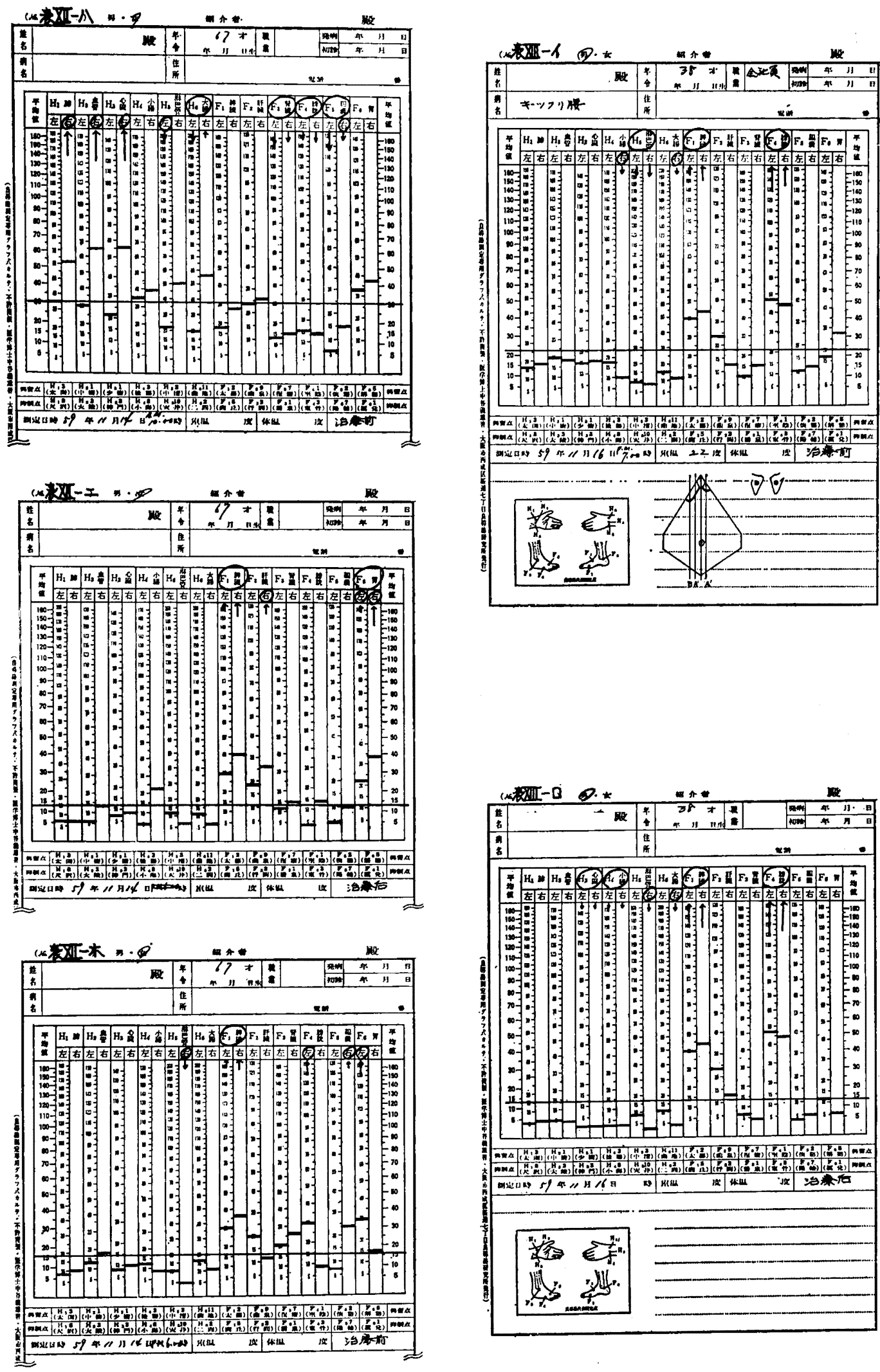